\title{
Knowledge Organization Landscape: A Content Analysis of Introductory Courses.
}

\author{
M. Cristina Pattuelli ${ }^{1}$ \\ School of Information and Library Science, Pratt Institute, New York, NY, USA
}

\begin{abstract}
This paper presents the results of a study examining the subject content of knowledge organization courses taught in ALA-accredited LIS programs. Close to 2,000 course readings of introductory-level knowledge organization courses from 34 Library and Information Science (LIS) schools in the U.S. and Canada were analyzed and indexed. Results indicate that traditional bibliographic methods and practices remain at the core of knowledge organization courses. Findings also show that metadata has become a central component of course content and new topics from information architecture to markup languages and semantic web are becoming part of introductory-level knowledge organization education.
\end{abstract}

Keywords: knowledge organization; education; information organization

\section{Introduction}

Undeniably, knowledge organization lies at the very heart of library and information science. As Library and Information Science (LIS) rapidly evolves and the digital dimension becomes increasingly pervasive, the role and scope of the knowledge organization curriculum is also evolving. This paper presents the results of a study examining the subject content of knowledge organization courses taught in ALA-accredited LIS programs. The study aims at gaining an understanding of what content is covered in introductory-level knowledge organization courses in LIS schools. The overall goal is to help understand whether introductory knowledge organization education is responding to the evolving areas of expertise required of today's information professionals. The study is intended to offer elements of discussion on the design requirements of knowledge organization courses and, in general, on requisites knowledge organization education should possess to educate future LIS professionals to meet the demands of the twenty-first century workplace.

\footnotetext{
${ }^{1}$ Correspondence to: M. Cristina Pattuelli, School of Information and Libray Science, Pratt Institute, 144 West $14^{\text {th }}$ Street, New York, 10011-7301,USA, mpattuel@pratt.edu
} 


\section{Cristina Pattuelli}

\section{Review of the literature}

Technology has deeply impacted the way we organize and represent information and knowledge. The escalating growth of digital information and the continuous advancement of information dissemination and retrieval systems have challenged the traditional models of access mediation. The wide array of discovery methods and services now available, from institutional repositories to commercial search engines and RSS feeds, has challenged the centrality of the library catalogue as a discovery tool [1]. While evolving, the effectiveness and usability of OPACs have also been brought into question [2]. The new ways in which people find and use information has forced the library community to redefine the traditional model of bibliographic control as a condition for libraries to remain relevant [3]. Recent additions to the literature have contributed to the debate on the future of cataloguing, including Byrd [4], Calhoun [5], Gorman [6], and Marcum [7], and reports from the Library of Congress [8] and the University of California Libraries [9]. Ivey [10] offers an articulate account of the issues at stake in the debate. The 'catalogue discussion' continues to be at the forefront among the LIS community in its effort to identify new models and strategic directions to provide access to recorded information. To promote research on cataloguing as well as on the role and the use of the catalogue, the American Library Association ALCTS (Association for Library Collections \& Technical Services) Implementation Task Group on the Library of Congress Working Group Report has declared 2010 to be the Year of Cataloguing Research [11].

The cataloguer's workplace is also rapidly changing and it is hard to predict the future of technical services [12]. Traditional divisions of responsibility are blurring and cataloguing departments are shrinking with traditional cataloguing increasingly transferred to paraprofessionals or outsourced. A significant number of cataloguers are expected to retire in the next decade and when they do they are likely to be replaced by other types of librarians fulfilling different roles. Whether this prediction is due to library administrators responding to shifting priorities or a shortage of professional cataloguers coming into the field without the skill set needed for an evolving information environment, LIS programs need to pay attention. While cataloguing competencies remain essential to the profession, traditional cataloguing duties, however they are defined, are less central to the organization. Wolven [13] contends that the mission and the duties of cataloguers have become increasingly ambiguous, shifting from traditional library collections to other types of content, primarily electronic, that require a new set of methods and skills.

Hall-Ellis [14] and Mugridge [15], among others, have recently investigated the type and range of competencies and skills cataloguers should possess when they enter the profession as well as the expectations held by employers. In the context of academic libraries, a basic understanding of cataloguing is considered necessary to provide good services to the academic community. Such competencies are critical for performing a variety of tasks, from interpreting bibliographic records to retrieving information [16]. As Calhoun [17] points out, it is likely that with the rapid changes in access services, resource description and knowledge organization skills will become less exclusive to cataloguers and increasingly part of the competencies of acquisition, reference, and information technology staff.

Just as the cataloguing profession faces critical challenges and traditional practices are questioned, cataloguing education has also come under scrutiny. A significant body of literature has been devoted to discussing the state of cataloguing education with a focus on curriculum requirements for cataloguing in master's level programs and core competencies and skills needed for cataloguer's careers [18]. Results of recent surveys have shown that cataloguing courses have declined in number as required courses, while LIS programs are increasingly relying on introductory courses to provide cataloguing and metadata education [19,20]. Joudrey [21] explored the state of graduate education of cataloguing and knowledge organization education through a longitudinal study that started in 2000. As the author notes in a recent article focused on curricular aspects of cataloguing education, a terminological shift has occurred where the use of the phrase "cataloguing education" has been often replaced by the more encompassing phrase "organization of information (OI) education" [22]. Joudrey's study shows that the listings of organization of information courses has steadily increased over the years and, as for 2005, each of the ALA-accredited LIS programs taught at least one OI course, while the average offering was four. All schools except two required some level of introduction to information organization that was fulfilled by an OI course rather than by a traditional cataloguing one. As Letarte, Turvey, Borneman, and Adams 


\section{Cristina Pattuelli}

[16] note, such courses may be the only place where students are exposed to the principles and methods of cataloguing and the only course that provides a foundation for students interested in a professional cataloguing career.

The challenges posed by the increasingly complex information systems and the proliferation of publishing through all types of media and formats make the need and value of resource description and representation even more critical [23]. A study by Beheshti [24] on curriculum changes in LIS programs in the U.S. and Canada conducted more than ten years ago relates the growth of knowledge organization as a subject area covered in LIS programs to the proliferation of digital resources. The practice of knowledge organization and representation is indeed at the core of digital libraries. For example, knowledge organization methods, tools, and practices are an intrinsic part of the $5 \mathrm{~S}$ model ${ }^{2}$ developed by Fox and his students at Virginia tech as the theoretical framework for digital library programs [25]. The Curriculum Development for Digital Libraries, a project developed by the Virginia Tech Department of Computer Science and the University of North Carolina School of Information and Library Science [26], identifies ten core topic areas in digital library research and education. Knowledge organization is listed as module four and includes four sub-modules on related topics such as metadata, ontologies, controlled vocabularies, and bibliographies [27].

In a workshop on digital libraries education at the Joint Conference on Digital Libraries (JCDL) in 2006, Smith and Rasmussen reported on a study of the specific knowledge required of future digital library professionals [28]. The study revealed that metadata and markup languages are among the most important and desired information technology knowledge in digital librarianship. The role of metadata in relation to cataloguing has been at the center of discussions taking place within the education community [29]. Questions range from what the core competencies in the areas of cataloguing and metadata should be and how should the more traditional cataloguing education be balanced with that needed for metadata.

Studies investigating topics addressed in introductory organization courses are sparse. Results from a faculty survey on cataloguing and metadata education conducted by Hsieh-Yee [20] show that introductory organization courses cover several aspects of cataloguing even though at a very basic level and provide only an overview of metadata. The study indicates that although a wide range of cataloguing topics are covered, there is considerable disparity among courses. Topics include: subject cataloguing; descriptive cataloguing, MARC and encoding standards, authority control, metadata, principles and purposes of the catalogue and cataloguing, bibliographic records, and bibliographic utilities.

Morgan \& Bawden [30] analyze the content of knowledge organization courses focusing on academic institutions, employers, and educators in the U.S, UK, and Australia. Results reveal an unexpected appreciation for theory over practice. While the types of skills and range of competences tend to change rapidly, a sound conceptual background such as that gained through formal education was highly valued by most respondents, including employers. As for topic areas, cataloguing and classification, which included taxonomies and ontologies, were regarded as the core of knowledge organization, while abstracting was considered less relevant than indexing because of its limited application.

As for the more general context of the field of knowledge organization, a recent study by Saumure and Shiri [31] explores knowledge organization literature trends comparing pre- and post-web eras. Their findings reveal the emergence of new thematic areas, such as metadata, while core knowledge organization principles remain dominant throughout the two eras. A notable contrast is represented by a shift in the literature of indexing and abstracting (I\&A). A prevalent topic in the literature before the advent of the web, I\&A quickly faded as cataloguing and classification became increasingly prominent.

\footnotetext{
${ }^{2}$ The 5S model comprises the dimensions of Structure, Scenario, Spatial, Society, and Stream. Within this model, 'catalog', 'structural metadata', 'descriptive metadata', and 'taxonomy' are related to the Structure element, while 'indexing' is inherent in the Space element.
} 


\section{Cristina Pattuelli}

\section{Study Overview}

As the literature shows, knowledge organization courses remain at the core of LIS curricula and are often offered as a required course for ALA-accredited LIS programs. Although they fall under an array of different labels ranging from "Organizing Information" to "Information Processing in Library and Information Science", they have often taken the place of introductory cataloguing courses. More than just semantics, this shift reflects a level of ambiguity over what such a course should address and what expectations students have when they enroll. What are we talking about when we talk about knowledge organization in LIS education? With this general question in mind, a study was designed to investigate the current topical coverage of knowledge organization courses taught in LIS schools in the U.S and Canada. Specific research questions the study intends to answer are:

1. What content is covered in knowledge organization courses in North American LIS schools today?

2. To what extent are these topics covered?

Building on the author's pilot study that focused on the top ten LIS schools in North America [32], this study extends the same methodology and analysis to the entire population of 57 ALA-accredited schools.

\section{Method}

A collection of syllabi of knowledge organization courses was conducted during spring 2008 for the population of all the 57 ALA-accredited LIS schools in North America and Canada. All programs offered at least one course on knowledge organization. Syllabi were acquired from websites when available, and through direct solicitation via email to instructors and school administrative offices. A total of 63 syllabi from 36 schools $(63 \%)$ were collected. Four syllabi could not be included because class readings were not listed. As a consequence, two schools could not provide data for the study and were removed from consideration. The collection of syllabi proved to be more challenging than anticipated mostly due to the insufficient information found in several schools' websites that made it difficult to identify even basic course information including instructor's name and number of sections taught. As mentioned earlier, introductory-level organization courses are identified by a wide variety of titles that can be confusing and often require additional verification.

A content analysis of 59 syllabi was performed with the primary goal of determining the range and the frequency of topics addressed in the courses. A total of 1,992 class readings were identified of which 1,976 were used as sources of data. Sixteen lacked even minimal bibliographic information and were therefore deemed not useable for the study. Bibliographic data were entered in a spreadsheet, normalized, and mapped onto corresponding individual class sessions, course titles, and relative schools. Ranging from printed book chapters to online articles, the class readings served as units of analysis. Each reading was analyzed based on content and context (e.g., corresponding course sessions and neighbour readings within the session) and later indexed. One index term was assigned to each reading. Where a reading addressed multiple topics, the most general and comprehensive term was chosen. For example, a reading on thesauri, ontologies, and topic maps was indexed as controlled vocabularies. A total of 43 index terms were applied [See Table 1]. 


\section{Cristina Pattuelli}

\begin{tabular}{lll}
\hline abstracting & data models & library buildings \\
archives & descriptive cataloguing & markup languages \\
arrangement and display & digital libraries & metadata (general) \\
authority control & encoding standards & metadata standards \\
bibliographic classification schemes & folksonomies & online library catalogues \\
bibliographic formats and standards & history of information organization & ontologies \\
bibliographic records & human-computer interaction & personal information management \\
catalogue management & indexing & semantic web \\
cataloguing principles and methods & information organization theory & subject cataloguing \\
cataloguing professions & information retrieval & taxonomies \\
citation analysis & information seeking & thesauri \\
classification and categorization & information theory & user behaviour \\
classification systems & knowledge management & vocabulary control tools \\
collection development & knowledge representation & web 2.0
\end{tabular}

Later, index terms were grouped in 15 general categories to assist in the identification of subject areas [See Table 2]. The indexing process was inductive and iterative. To enforce consistency, each reading was indexed by two coders independently. Discrepancies were reconciled through iterative negotiation and terms were normalized, whenever possible, using the ASIST thesaurus [33].

Table 2

List of Subject Areas

archives

bibliographic control

classification

digital libraries

information architecture

information organization

information retrieval

information theory

knowledge management

knowledge representation

metadata

semantic web

subject access and vocabulary control

user behaviour

web 2.0 


\section{Cristina Pattuelli}

\section{Results}

Frequency of readings provided the primary metric for determining the content of knowledge organization courses. Figure 1 shows the extent of the subject areas and offers a bird's-eye view of the entire readings content space.

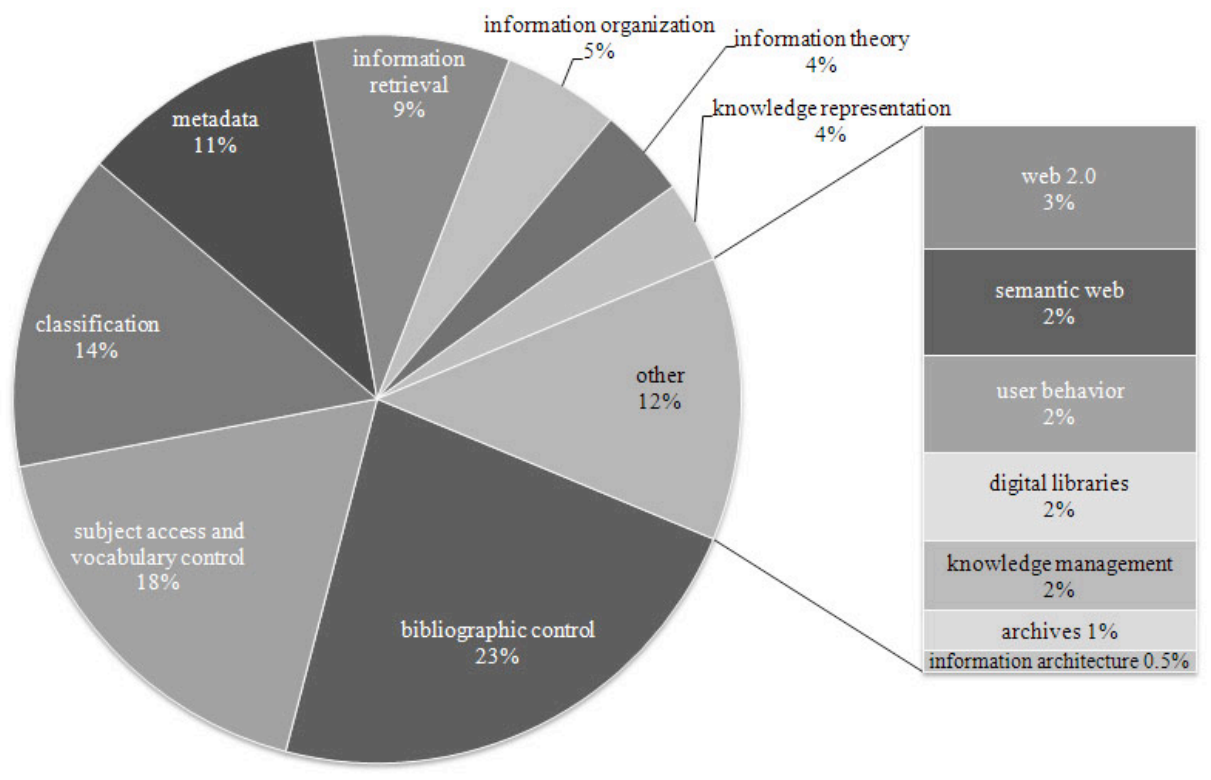

Fig. 1. Subject areas covered in course syllabi.

As the chart indicates, traditional bibliographic subject areas are the most extensively covered. Bibliographic control represents the broadest area with a rate of $23 \%$ followed by subject access and vocabulary control (18\%) and classification (14\%). Metadata (11\%) and information retrieval $(9 \%)$ are the top fourth and fifth subject areas covered. Tabulation of article topics is presented in table 3 . 


\section{Cristina Pattuelli}

Table 3

Summary of subject areas in course syllabi

\begin{tabular}{lrr}
\hline Subject Areas & Frequency \\
$\mathrm{N}=1,976$ & Percentage \\
\hline bibliographic control & 450 & $23 \%$ \\
subject access and vocabulary control & 355 & $18 \%$ \\
classification & 280 & $14 \%$ \\
metadata & 218 & $11 \%$ \\
information retrieval & 172 & $9 \%$ \\
information organization & 102 & $5 \%$ \\
knowledge representation & 72 & $4 \%$ \\
information theory & 79 & $4 \%$ \\
web 2.0 & 56 & $3 \%$ \\
knowledge management & 32 & $2 \%$ \\
digital libraries & 40 & $2 \%$ \\
user behaviour & 44 & $2 \%$ \\
semantic web & 48 & $2 \%$ \\
information architecture & 10 & $1 \%$ \\
archives & 18 & $1 \%$ \\
\hline
\end{tabular}

At a more granular level, scope and frequency of topics is illustrated in figure 2. 


\section{Cristina Pattuelli}

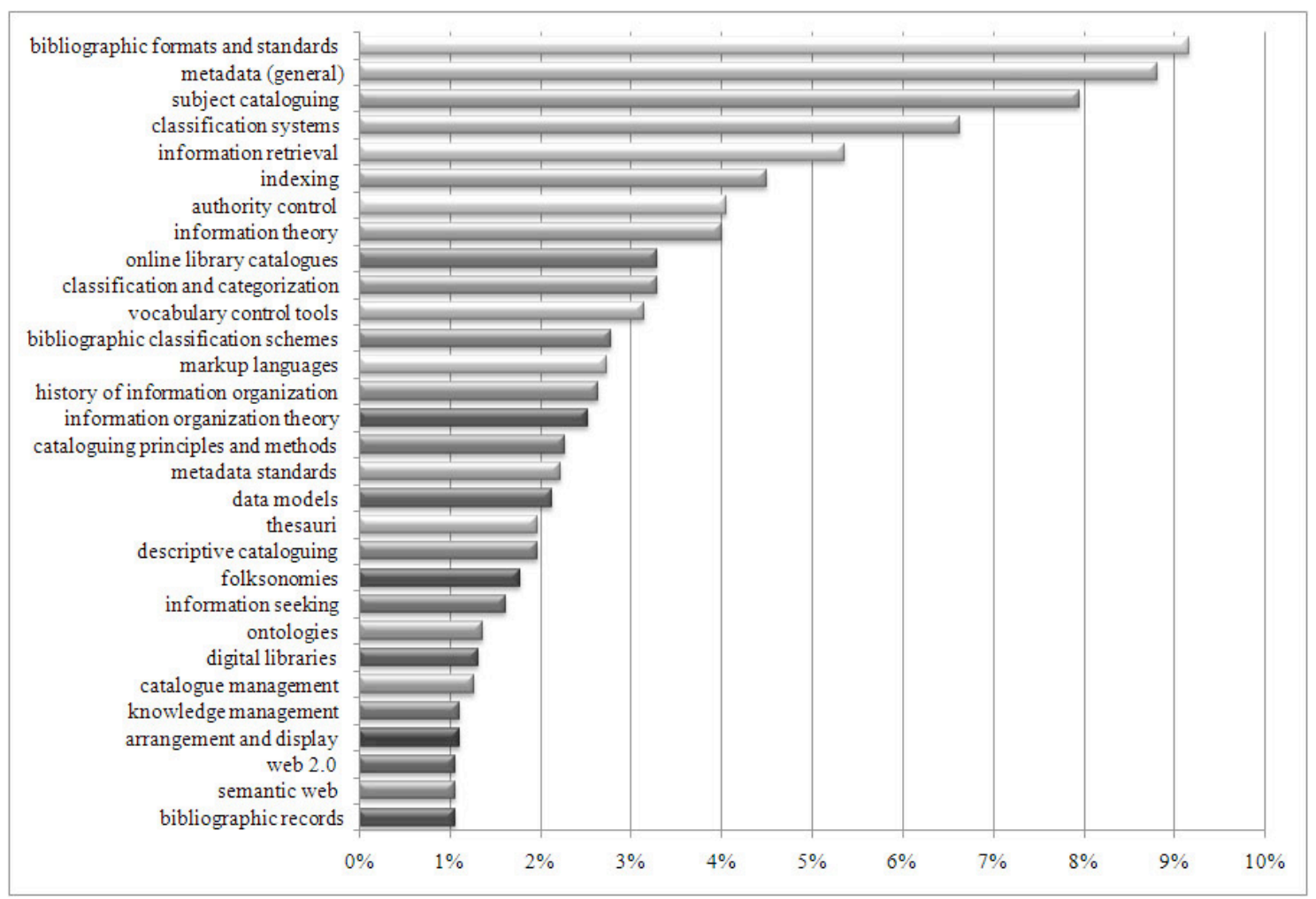

Fig. 2. Frequency of topics in course syllabi. (The vertical axis was trimmed of terms that occurred less than 20 times in order to preserve diagram clarity).

The dominant topic is bibliographic formats and standards (181 occurrences or 9.2\%). This topic is indeed representative of a variety of tools ranging from Anglo-American Cataloguing Rules (AACR2) to RDA (Resource Description and Access). This topic is covered even more extensively if we consider it together with the related topic data models (42 occurrences or $2.1 \%$ ) which primarily refers to FRBR (Functional Requirements for Bibliographic Records). The complete list of topics is shown in table 4.

Table 4

Summary of topics in course syllabi

\begin{tabular}{lll}
\hline Topics & Frequency & Percentage \\
& $\mathrm{N}=1,976$ & \\
\hline bibliographic formats and standards & 181 & $9.2 \%$ \\
metadata (general) & 174 & $8.8 \%$ \\
subject cataloguing & 157 & $7.9 \%$ \\
classification systems & 131 & $6.6 \%$ \\
information retrieval & 106 & $5.4 \%$ \\
indexing & 89 & $4.5 \%$ \\
information theory & 79 & $4.0 \%$ \\
authority control & 80 & $4.0 \%$ \\
classification and categorization & 65 & $3.3 \%$ \\
online library catalogue & 65 & $3.3 \%$
\end{tabular}




\section{Cristina Pattuelli}

\begin{tabular}{lll} 
vocabulary control tools & 62 & $3.1 \%$ \\
bibliographic classification schemes & 55 & $2.8 \%$ \\
markup languages & 54 & $2.7 \%$ \\
history of information organization & 52 & $2.6 \%$ \\
information organization theory & 50 & $2.5 \%$ \\
cataloguing principles and methods & 45 & $2.3 \%$ \\
metadata standards & 44 & $2.2 \%$ \\
data models & 42 & $2.1 \%$ \\
descriptive cataloguing & 39 & $2.0 \%$ \\
thesauri & 39 & $2.0 \%$ \\
folksonomies & 35 & $1.8 \%$ \\
information seeking & 32 & $1.6 \%$ \\
ontologies & 27 & $1.4 \%$ \\
catalogue management & 25 & $1.3 \%$ \\
digital libraries & 26 & $1.3 \%$ \\
bibliographic records & 21 & $1.1 \%$ \\
semantic web & 21 & $1.1 \%$ \\
web 2.0 & 21 & $1.1 \%$ \\
arrangement and display & 22 & $1.1 \%$ \\
knowledge management & 22 & $1.1 \%$ \\
archives & 18 & $0.9 \%$ \\
knowledge representation & 1 & $0.9 \%$ \\
encoding standards & 18 & $0.7 \%$ \\
collection development & 14 & $0.7 \%$ \\
personal information management & 14 & $0.5 \%$ \\
information architecture & 9 & $0.5 \%$ \\
taxonomies & 10 & $0.4 \%$ \\
abstracting & 7 & $0.4 \%$ \\
user behaviour & 8 & $0.4 \%$ \\
cataloguing professions & 3 & $0.2 \%$ \\
human computer interaction & & $0.2 \%$ \\
library buildings & $1 \%$ \\
citation analysis & $3 \%$ \\
\hline
\end{tabular}

\section{Discussion}

Results indicate that traditional bibliographic methods and systems are at the core of course content. These results are largely aligned with the literature that identifies traditional knowledge organization areas as the most prominent in knowledge organization courses. This study confirms the findings of previous studies that have also pointed out that a broad range of cataloguing topics are addressed in these courses. A rich bibliographic universe 


\section{Cristina Pattuelli}

emerges encompassing different types of formats and standards as well as materials and practices. The topic of metadata appears to have increased its presence and depth beyond that reported by Hsieh-Yee [20]. Metadata makes up a considerable portion of course content with a total of 218 occurrences $(11 \%), 174$ occurrences $(8.8 \%)$ of metadata (general) and 44 occurrences (2.2\%) of metadata standards.

In general, the spectrum of topics addressed in course readings is far broader than traditional cataloguing classes. Topics from different fields and traditions are represented including both established and emerging knowledge organization systems such as thesauri (39 occurrences or $2 \%$ ), folksonomies (35 occurrences or $1.8 \%$ ) and ontologies (27 occurrences or 1.4\%).

On the other end of the spectrum, a traditional knowledge organization topic such as abstracting appears to be infrequently represented with a rate of $0.4 \%$ and 8 occurrences confirming Morgan \& Bawden's findings [30]. Conversely, the topic of indexing is well represented with 89 occurrences $(4.5 \%)$ confirming its centrality in the field.

An interesting finding is the presence of the emerging topic personal information management represented by 9 occurrences $(0.5 \%)$. The topic broadens the context of knowledge organization outside the traditional institutional boundaries.

The results show that a growing segment of course content is devoted to topics that have direct implications for electronic resources and digital libraries in particular, including metadata (11\%), information retrieval (8.7\%), and knowledge representation (0.9\%). In fact, digital libraries are often addressed as a standalone topic (2\%). Other subject areas potentially relevant to networked electronic environments are knowledge representation (3.6\%), web $2.0(2.8 \%)$, semantic web (2.4\%), and information architecture $(0.5 \%)$. The knowledge requirements identified in the literature review as essential to future digital library professionals seem to be well represented in the study's results, including metadata and markup languages, which were deemed to be among the most important and desired information technology knowledge for digital librarianship by Smith and Rasmussen [34].

Issues of system design and usability are also represented prominently including information retrieval (5.4\%), and information architecture $(0.5 \%)$. The user perspective is another dimension increasingly addressed through various approaches including information seeking (1.6\%), user behaviour (0.4\%), and human-computer interaction $(0.2 \%)$.

It is important to note that a substantial portion of course content is devoted to theoretical topics including information theory (4\%), history of information organization (2.7\%), and information organization theory (2.5\%) contributing to a more balanced approach between theory and applications.

Course readings were also computed and a core of 15 most frequently assigned readings (those occurring more than 10 times) was identified.

Table 3

Most frequently assigned course readings.

\begin{tabular}{|c|c|c|}
\hline & Reading & \# \\
\hline 1. & $\begin{array}{l}\text { American Library Association, Canadian Library Association and The Chartered Institute on Library and Information } \\
\text { Professionals. (2002). Anglo-American Cataloguing Rules, 2nd ed. Chicago: American Library Association. }\end{array}$ & $\begin{array}{l}4 \\
0\end{array}$ \\
\hline 2 . & $\begin{array}{l}\text { Taylor, A. (2004). Chapter 11: Systems for Categorization. In The Organization of Information, } 2^{\text {nd }} \text { ed. Westport, CT: Libraries } \\
\text { Unlimited }\end{array}$ & $\begin{array}{l}2 \\
9\end{array}$ \\
\hline 3. & $\begin{array}{l}\text { Furrie, B. (2003). Understanding MARC Bibliographic: Machine Readable Cataloguing. Available at } \\
\text { http://www.loc.gov/marc/umb/. }\end{array}$ & $\begin{array}{l}2 \\
9\end{array}$ \\
\hline 4. & $\begin{array}{l}\text { Taylor, A. (2004). Chapter 10: Systems for Vocabulary Control. In The Organization of Information, } 2^{\text {nd }} \text { ed. Westport, CT: } \\
\text { Libraries Unlimited. }\end{array}$ & $\begin{array}{l}2 \\
7\end{array}$ \\
\hline 5. & Taylor, A. (2004). Chapter 9: Subject Analysis. In The Organization of Information, $2^{\text {nd }}$ ed. Westport, CT: Libraries Unlimited. & $\begin{array}{l}2 \\
2\end{array}$ \\
\hline
\end{tabular}




\section{Cristina Pattuelli}

6. Taylor, A. (2004). Chapter 8: Metadata: Access and Authority Control. In The Organization of Information, $2^{\text {nd }}$ ed. Westport, 2 CT: Libraries Unlimited.

7. Taylor, A. (2004). Chapter 4: Encoding Standards. In The Organization of Information, $2^{\text {nd }}$ ed. Westport, CT: Libraries 2 Unlimited.

8. Taylor, A. (2004). Chapter 1: Organization of Recorded Information. In The Organization of Information, $2^{\text {nd }}$ ed. Westport, CT: 1 Libraries Unlimited.

9. Taylor, A. (2004). Chapter 2: Retrieval Tools. In The Organization of Information, $2^{\text {nd }}$ ed. Westport, CT: Libraries Unlimited.

10. Taylor, A. (2004). Chapter 3: Development of the Organization of Recorded Information in Western Civilization. In The 1 Organization of Information, $2^{\text {nd }}$ ed. Westport, CT: Libraries Unlimited.

11. Taylor, A. (2004). Chapter 7: Metadata: Description. In The Organization of Information, $2^{\text {nd }}$ ed. Westport, CT: Libraries 1 Unlimited.

12. Taylor, A. (2004). Chapter 5: Systems and System Design. In The Organization of Information, $2^{\text {nd }}$ ed. Westport, CT: Libraries 1 Unlimited.

13. Taylor, A. (2004). Chapter 12: Arrangement and Display. In The Organization of Information, $2^{\text {nd }}$ ed. Westport, CT: Libraries 1 Unlimited.

14.

Taylor, A. (2004). Chapter 6: Metadata. In The Organization of Information, $2^{\text {nd }}$ ed. Westport, CT: Libraries Unlimited. 2

15. Tillet, B. (2004). What is FRBR: a Conceptual Model for the Bibliographic Universe. Available at 1 http://www.loc.gov/cds/downloads/FRBR.PDF.

As table 3 shows, the top 15 readings cover a wide spectrum of topics. The Anglo-American Cataloguing Rules (AACR2) manual is ranked highest with 40 occurrences while the textbook The Organization of Information by Arlene Taylor is the main source of the most frequently assigned readings.

Overall, results indicate a profile of organization courses grounded in traditional bibliographic practices, but inclusive of methods and techniques aimed at electronic resources (e.g., metadata, markup languages, encoding standards, etc.), and applicable to different types of information systems and environments (e.g., digital libraries and archives). This finding suggests that organization courses are starting to move beyond institutional boundaries toward a more unified idea of information systems and services.

The broad scope of the topics, although present with varied rates of frequency, appears to reflect the evolving state of a field that is growing more complex and multifaceted.

\subsection{Limitations}

The author recognizes a number of limitations of the study. First, the source of data: while course readings are indubitably an important component of instruction, they offer only a partial picture of what is covered in a course where a variety of instructional materials and educational opportunities contribute to the learning experience. Also, the sample of course readings, while extensive, is not exhaustive and therefore cannot present the complete topical coverage of knowledge organization courses for the time frame considered.

Also, the indexing process presents the limits of human analysis including personal biases, accuracy, and consistency. To enforce data reliability two coders have performed content analysis and indexing independently 


\section{Cristina Pattuelli}

and reconciled discrepancies through iterative revisions. To reduce ambiguity, index terms were drawn, whenever possible, from domain specific lists of controlled terms, including ASIS\&T thesaurus. Other vocabulary tools consulted, including thesauri from major LIS databases and access services such as H.W. Wilson Company Database and Library and Information Science Abstracts (LISA), were of limited help being often not specific enough or not inclusive of relevant topics such as markup languages or encoding standards.

\section{Conclusion and future work}

This paper presents the results of a study examining subject content of knowledge organization courses taught in ALA-accredited LIS programs. Close to 2,000 course readings of introductory-level knowledge organization courses from 59 syllabi were analyzed and indexed. Results indicate that traditional bibliographic methods and practices remain at the core of knowledge organization courses. Findings also show that metadata has become a central component of course content. New topics from different traditions and practices have also made it in to the curriculum. It is not uncommon for topics like information architecture and semantic web to be present alongside subject cataloguing and bibliographic classification schemes. The breadth of the content scope with its array of new and emerging topics relevant to different types of information environments found in introductory-level knowledge organization education seems to reflect a field in evolution.

Knowledge organization education faces challenges similar to those that LIS education programs in general are facing: redefining its role and restructuring the curriculum to respond to a changing profession. Core competences need to evolve in response to the changes taking place in professional practices and the new areas of expertise needed for today's library and information work environment. This study offers a snapshot of the state of introductory knowledge organization education that provides context for a broader discussion of the characteristics that knowledge organization education needs to meet the challenges of a profession and a discipline in flux. Replication of this study over time would offer an opportunity to identify trends and monitor patterns of change. More research is needed to gain a deeper and more comprehensive view of knowledge organization education that should include the various instructional perspectives and approaches to knowledge organization teaching and learning and contribute to the "construction of knowledge organization as a field of learning" [35].

\section{References}




\section{Cristina Pattuelli}

[1] L. Dempsey, The library catalogue in the new discovery environment: some thoughts, Ariadne 48 (July 2006). Available at: http://www.ariadne.ac.uk/issue48/dempsey/ (accessed 27 July 2010).

[2] J. Mi and C. Weng, Revitalizing the library OPAC: interface, searching, and display challenges, Information Technology and Libraries 27(1) (2008) 5.

[3] Library of Congress. On the Record: Report of the Library of Congress Working Group on the Future of Bibliographic Control. (Washington, D.C.: Library of Congress, 2008). Available at: http://www.loc.gov/bibliographic-future/news/lcwg-ontherecord-jan08-final.pdf (accessed 20 July 2010).

[4] J. Byrd, A White Paper on the Future of Cataloging at Indiana University, White Paper prepared for Indiana University (January 15, 2006). Available at:

http://www.iub.edu/ libtserv/pub/Future_of_Cataloging_White_Paper.pdf (accessed 12 July 2010).

[5] K. Calhoun, The Changing Nature of the Catalog and its Integration with Other Discovery Tools: Final Report, prepared for the Library of Congress (March 17, 2006). Available at: http://www.loc.gov/catdir/calhoun-report-final.pdf (accessed 12 July 2010).

[6] M. Gorman, Why teach cataloguing and classification?, Cataloging \& Classification Quarterly 34(1-2) (2002) 1-2.

[7] D.B. Marcum, The future of cataloging, Library Resources and Technical Services 50(1) (2006) 5-9.

[8] Library of Congress. On the Record: Report of the Library of Congress Working Group on the Future of Bibliographic Control (January 8, 2008). Available at: http://www.loc.gov/bibliographic-future/news/lcwgontherecord-jan08-final.pdf (accessed 27 July 2010).

[9] The University of California Libraries Bibliographic Services Task Force, Rethinking How We Provide Bibliographic Services for the University of California, Final Report: December 2005. Available at: http://libraries.universityofcalifornia.edu/sopag/BSTF/Final.pdf (accessed 3 July 2010).

[10] R.T. Ivey, Perceptions of the future of cataloging: is the sky really falling?, Cataloging and Classification Quarterly 47(5) (2009) 464-482.

[11] A. Carlyle, Invited Editorial: Announcing 2010, Year of Cataloging Research, Cataloging and Classification Quarterly 47(8) (2009) 687-690. Available at: http://catalogingandclassificationquarterly.com/ccq47nr8.html\#editorial (accessed 27 July 2010).

[12] B.L. Eden, The new user environment: The end of technical services?, Information Technology and Libraries 29(2) (2010) 93-100.

[13] R. Wolven, In search of a new model, Library Journal (1976) (Winter 2008): 6-9. Library Lit \& Inf Full Text (accessed 24 July 2010).

[14] S. Hall-Ellis, Cataloger competencies... what do employers require?, Cataloging \& Classification Quarterly 46(3) (2008) 305-330.

[15] R.L. Mugridge, Experiences of newly-graduated cataloging librarians, Cataloging \& Classification Quarterly 45(3) (2008) 61-79.

[16] K.M. Letarte, M.R. Turvey, D. Borneman, and D.L. Adams, Practitioner perspectives on cataloging education for entry-level academic librarians, Library Resources \& Technical Services 46(1) (2002) 11-22.

[17] K. Calhoun, Redesign of Library Workflows: Experimental Models for Electronic Resource Description, Prepared for the Library of Congress, Bicentennial Conference on Bibliographic Control for the New Millennium, (December 2000). Available at: http://lcweb.loc.gov/catdir/bibcontrol/calhoun_paper.html (accessed 20 July 2010).

[18] J. Swan Hill, ed., Education for Cataloging and the Organization of Information: Pitfalls and the Pendulum, (New York, Haworth, 2002).

[19] J.M. Davis, A survey of cataloging education: are library schools listening?, Cataloging \& Classification Quarterly 46(2) (2008) 182-200. 


\section{Cristina Pattuelli}

[20] I. Hseih-Yee, Cataloging and metadata education in North American LIS programs, Library Resources \& Technical Services 48(1) (2004) 59-68.

[21] D. Joudrey, A new look at US graduate courses in bibliographic control, Cataloging \& Classification Quarterly 34(1/2) (2002) 57-99.

[22] D. Joudrey, Another look at graduate education for cataloging and the organization of information, Cataloging \& Classification Quarterly 46(2) (2008) 137-181.

[23] A. Danskin, "Tomorrow never knows": the end of cataloguing?, IFLA Journal 33(3) (2007) 205-209.

[24] J. Beheshti, Library and information studies curriculum, In: Proceedings of the Congress on Professional Education (Chicago, IL: American Library Association, 1999).

[25] M.A.Gonçalves, E.A. Fox, L.T. Watson, and N.A. Kipp, Streams, structures, spaces, scenarios, societies (5s): a formal model for digital libraries, ACM Transactions on Information Systems (TOIS) 22(2) (2004) 270-312.

[26] Virginia Tech and University of North Carolina Chapel Hill, Digital Libraries Curriculum Development Project, Module framework (September 16, 2007). Available at: http://curric.dlib.vt.edu/DLcurric_images/ModuleFramework.2007-09-16.pdf (accessed 27 July 2010).

[27] J. Pomerantz, S. Oh, S. Yang, E.A. Fox, and B.M. Wildemuth, 2006. The core: digital library education in library and information science programs," D-Lib Magazine 12(11) (November 2006). Available at: http://www.dlib.org/dlib/november06/pomerantz/11 pomerantz.html (accessed 15 July 2010).

[28] K. Brancolini and J. Mostafa, Developing a digital libraries education program, JCDL 2006 workshop report, D-Lib Magazine 12(7/8) (2006).

[29] Library of Congress, Archives of eduCAT Discussion List. Available at: http://listserv.loc.gov/listarch/educat.html (accessed 27 July 2010).

[30] J. Morgan and D. Bawden, Teaching knowledge organization: educator, employer and professional association perspectives, Journal of Information Science 32(2) (2006) 108-115.

[31] K. Saumure and A. Shiri. 2008. Knowledge organization trends in library and information studies: a preliminary comparison of the pre- and post-web eras, Journal of Information Science 34(5) (2008) 651666.

[32] M.C. Pattuelli, Knowledge organization for digital library education: a discipline in flux. In: J. Selthofer, T. Aparac-Jelusic, \& M. Krtalic (eds.), Proceedings of the LIDA 2008 (Libraries in the Digital Age) Conference, Dubrovnik and Mljet, Croatia, June 2-7, 2008, 186-196.

[33] A. Redmond-Neal, M.K. Hlava, and J.L. Milstead. ASIS\&T Thesaurus of Information Science, Technology, and Librarianship. (ASIST monograph series. Medford, N.J.: Published for the American Society for Information Science and Technology by Information Today, Inc., 2005).

[34] K. Brancolini, and J. Mostafa, Developing a digital libraries education program, JCDL 2006 workshop report, D-Lib Magazine 12(7/8) (2006).

[35] B. Hjørland, (2008). Review of: G.G. Chowdhury and S. Chowdhury, Organizing information from the shelf to the Web, (London: Facet Publishing, 2007). Information Research 13(1) (2008) review no. R291. Available at: http://informationr.net/ir/reviews/revs291.html (accessed 31 July 2010). 